\title{
Sensitive memories at a World Heritage Site
}

\section{Silencing and resistance at the Valongo Wharf ${ }^{\prime}$}

\author{
Márcia Chuva, Leila Bianchi Aguiar and \\ Brenda Coelho Fonseca
}

The Valongo Wharf, built in 1811 in the Rio de Janeiro port region, became a World Heritage Site in 2017. It is regarded as a historic archaeological site for sensitive memory because nearly a million enslaved Africans arrived in Brazil through this port. In 1843, a re-urbanization project was carried out to build a new wharf for the arrival of Princess Tereza Cristina de Bourbon who had married D. Pedro II, the Emperor of Brazil, by proxy in Europe. From that moment, the place was called Empress Wharf (Cais da Imperatriz). During early twentieth-century urban reforms and Rio port renovations, the wharf was buried, giving way to the Comércio Square. After landfill renovation work, the area was further from the sea and took on a new character.

In 2011, the different layers of the wharf were unearthed while conducting renovation work for the Porto Maravilha project. ${ }^{2}$ This part of the city has been a hub for people of African descent since the first half of the nineteenth century, and in the early twentieth century people started referring to it as Pequena África (Little Africa). The Wharf and other urban locales - such as the Pretos Novos Cemetery, a place where Black Africans were buried in the nineteenth century, which will be addressed in this chapter, and Pedra do Sal, considered the cradle of samba in $\mathrm{Rio}^{3}$ - are traces and material remains of coloniality (Mignolo 2011). Coloniality is construed as a modern-colonial world system into which nineteenth-century Brazil was inserted. It is based on three tiers: modernity, slavery, and science. In Brazil, slavery was abolished in 1888. However, post-abolition events show that the modern-colonial world system, based on structural racism, still prevails. Racism in Brazil is the rule, not the exception, and is defined as discrimination against racialized people, in other words, those who 'coloniality manufactures as "the other" to be subjected to discrimination, exclusion, exploitation, disdain' (Vergès 2020, 18). Racial discrimination is more than simply a remnant of African slavery; even after the abolition of slavery, no measures were instituted to include formerly enslaved people in society (Araújo 2015). Although segregationist laws have never been enacted, such population groups have been marginalized economically, socially, and culturally. And post-abolition has become a long-lasting period with effects persisting to this day. Racism affecting people of African descent as well as native Indigenous peoples must be construed as 
pertaining to coloniality, which shapes society and turns discriminatory principles into second nature behaviours and actions. Therefore, structural racism can be defined as:

The hierarchy resulting from racism does not only affect society and its foreign relations - as in colonization - but affects, above all, society's internal structure, defining hierarchical patterns, making historic forms of domination commonplace and justifying state intervention on discriminated groups, which is the case for Black and Indigenous people ${ }^{4}$.

(de Almeida, 2018, 139-40)

This chapter considers a strategic understanding of heritage as an action concept, tied to history, seeking to avoid stagnant or essentialist perspectives to analyse Valongo Wharf as multiple pieces of heritage and memories in motion (Smith 2006). It is important to highlight the role played by the United Nations Educational, Scientific and Cultural Organization (UNESCO) in the process of recognizing sensitive memories as regards slavery and the transatlantic trade of enslaved Africans. Similarly, the relationships local agents establish with this colonial legacy, defining the experience of facing racism as an axis, manifested directly or indirectly in their statements. In this chapter, their narratives of denunciation and resistance are analysed.

To understand the symbolic meaning of the tensions related to designating the Wharf as a World Heritage Site, we have examined its application dossier, the list of World Heritage Sites selected over the last 20 years, and UN and UNESCO official international documents. For the relationships local agents have established with colonial legacy, priceless empirical material has been collected from interviews conducted between May and December 2019. While selecting interviewees, multiple social criteria and relationships with the port area territory have been taken into account. All interviewees are people of African descent and not representatives of social movements. They are delivering first-hand accounts and claim that their lives have been affected by the process of heritagization of the Wharf. These characteristics can be seen as a direct result of the need to expand processes of listening, producing, and disseminating memories and narratives about the past, highlighted by silencing of racialized groups, one of the many consequences of racism, a structural element of oppression in Brazil. In a context marked by increasing dehumanization and violence mainly targeting Black people, recording interviewees' narratives is ever more relevant because it is akin to keeping a record of stories of resistance and social agents who have been historically silenced (Trouillot 1995). It becomes an important tool for affirming narratives about a past rife with exclusion and violence and for reaffirming the importance of decolonial and anti-racist struggles in the present.

To conduct the interviews, we created flexible scripts. Our opening question addressed the impact of Valongo Wharf heritagization on the lives of 
participating subjects and the relationships established with the port area. We decided to keep interviewer remarks to the bare minimum, seeking instead to listen to personal narratives provided by interviewees. ${ }^{5}$ Statements by interviewees can be construed as important ways of recording processes to build diverse identities (Santos 2014), and oral history may be regarded as a tool for creating heritage (Thompson 2006). Both offer tools to amplify the participation of subjects directly involved in processes of heritagization. The fact that this material is so rich and specific does not allow for any kind of generalization. Opting for life stories allows for understanding individual narratives, which helps in the broader analyses of societies, as set forth by Paul Thompson (1990), and provides access to subjectivities. Thus, it offers one of the ways to displace centralities, causing discomfort within mainstream opinion and changes in attitude as regards the perspective of decolonization of heritage.

Therefore, while analysing the material, we have focused on Pretos Novos Cemetery and the Wharf. Although there are no paramount public cultural policies targeting the cemetery, narratives by our interviewees have placed it in a central position as the most vocal materiality of the dehumanization process enslaved Africans have been subjected to. The cemetery was found in 1996, long before the Valongo Wharf was located. During the renovations of a house on Pedro Ernesto Street, researchers were able, through archaeological investigations, to locate the burial plots of thousands of slaves. Through 2017, religious and household items were found, in addition to the evidence of 5,563 buried bodies, which have become objects of archaeological studies by researchers at Rio de Janeiro Federal University's National Museum - UFRJ (IPHAN 2017). Maria Merced Guimarães and Petrúcio Guimarães, owners of the house, immediately reported the findings to the city government and decided to convert the property into the Institute of Research and Memory Pretos Novos (IPN), a place displaying archaeological artefacts from the old cemetery, providing exhibitions, offering courses and guided tours on topics related to the diaspora and the presence of people of African descent in the region. ${ }^{6}$

\section{Placing the cemetery and the Wharf in World Heritage debates}

In 2017, the Valongo Wharf was registered on the UNESCO World Heritage List. The decision was based on the VI evaluation criterion, emphasizing the exceptional universal value of the site based on the association between past human rights violations, current resistance, and empowerment of people of African descent. The connections between the transatlantic trade of enslaved Africans, slavery in Brazil, the contemporary Black presence in the port area, and the traumatic and painful memories of that past embodied in the materiality of the Wharf have been highlighted. Advocating for the right to memory for people of African descent and reparation policies for centuries of slavery and racism are the main arguments set forth in the application 
dossier for acknowledging Valongo Wharf as a historic site of sensitive memory (IPHAN 2017; UNESCO 2017a) (Figure 9.1).

At the local level, the process of redemocratization of Brazil and the mobilization of Black movements while discussing Brazil's National Constituent Assembly have enabled the passing of laws criminalizing racism and setting up the Palmares Foundation in light of Brazil's 1988 New Federal Constitution. In addition, the Secretariat for Policies to Promote Racial Equality (SEPPIR) was founded in the 2000s. ${ }^{7}$ In the context of the United Nations (UN), it is important to highlight the Durban Conference held in South Africa in 2001, which placed racism at the centre of international debates. For the first time in history, slavery and the transatlantic trade of enslaved Africans were acknowledged as crimes against humanity. Such crimes are linked to the racism that shapes contemporary societies (UN 2001, 6). At the same event, the international community, and a major Brazilian entourage in Durban, praised UNESCO's Slave Route Project as an important initiative capable of breaking the silence around issues pertaining to slavery and the slave trade. With broad support from African countries, expressed at the 1992 meeting of the Organization of African Unity (OAU), UNESCO has taken up the project in compliance with demands presented by Haiti and Benin (OAU 1992; UNESCO 1993). Since then, a series of actions have been developed by member countries, including Brazil, which have resulted in the Inventory of Sites and Places of Memory of the Atlantic Slave Trade and the History of Enslaved Africans in Brazil $^{8}$ (Mattos et al. 2013, 2014).

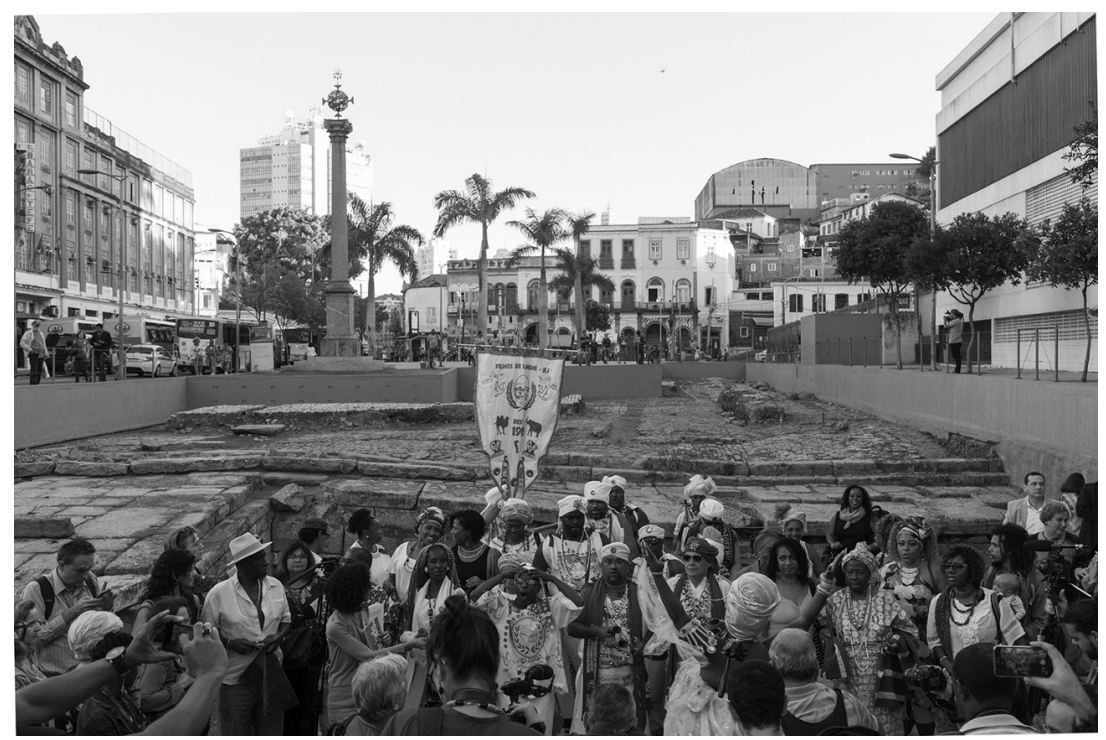

Figure 9.I Valongo Wharf. World Heritage dossier submission ceremony on 10 July 2017.

Photo courtesy Oscar Liberal. 
There is no doubt that debates held at the level of the UN represent an important change as regards questioning structural racism and implementing public reparation policies at different levels. With regard to Brazil, on the one hand, it is in this context that affirmative actions were carried out by President Luiz Inácio Lula da Silva's administration (2003-2010). On the other hand, the processes of heritagization on a global scale led by a Brazilian federal agency (IPHAN) have insisted on reproducing mainstream narratives about the colonial past by highlighting, under UNESCO's World Heritage seal, sites linked to European, white, and Catholic national portrayal. ${ }^{9}$

The World Heritage List reflects the mainstream heritage view, legitimated and systematically reiterated by UNESCO and its consultative agencies, which validate national narratives guided by the universal modern paradigm (Smith 2006). According to Laurajane Smith, the listing creates meanings, ' $[\mathrm{t}]$ he listing process creates or recreates sites as universally important and meaningful' $(2006,99)$. Her criticism fits the perspective of coloniality: what is regarded as universal, in fact, expresses Western modernity (Mignolo 2011). The meeting celebrating the 30th anniversary of the 1972 World Heritage Convention has not set the stage for confronting mainstream narratives nor have there been voices echoing the debates held in Durban the year before (UNESCO 2002, 7). Over the past 20 years, even though the largest number of registered sites come from European countries, there has been an increase in enrolments from countries belonging to the 'peripheral' regions..$^{10}$ However, monumental, aesthetic, and Eurocentric elements are still paramount on UNESCO's list. ${ }^{11}$

The Valongo Wharf case exposes the tensions and disputes surrounding heritage processes on local and global scales. As noted by Simone Vassallo and André Cicalo, local conflicts and the multiple points of view surrounding the candidacy of Valongo Wharf have been concealed by the consensus built for its recognition as a World Heritage Site $(2015,255)$. The final text submitted to UNESCO can be analysed in the context of its drafting as a result of provisional agreements between heterogeneous views and power relations at stake, between different agents and institutions. In this process, the performance of Black movements, researchers and two government institutions must be emphasized: the Palmares Foundation and the Secretariat for Racial Equality, at the time headed by Eloi Ferreira Araújo and Luiza Bairros, important Black militants who did significant work in the 1980s.

Although the World Heritage title granted to Valongo Wharf represents an effort to overcome mainstream opinions, which have been permeating national and international preservation policies, its materiality and aesthetic value have been strongly emphasized with its candidacy. Excluding Pretos Novos Cemetery from the central area set for protection, placing it only on the site's heritage 'buffer zone', ${ }^{12}$ shows there is still a lot of work to do to overcome mainstream narratives. Such designation highlights the secondary place the cemetery holds in the heritagization process, reinforcing the more than a decade-long silencing practices since finding the remains of enslaved 
Africans. ${ }^{13}$ For example, the 2016 International Council of Monuments and Sites (ICOMOS) report silenced the voices of history by suggesting that

solely the elements which the site can represent within its boundaries by critically reviewing the contribution and inclusion of elements such [as] the quarantine facilities, store houses, market of enslaved people and the New African Cemetery, which do not seem localized within the present boundaries or are not known or represented in archaeological remains.

(ICOMOS 2016, 2)

Such silencing can also be seen in a quick review of the iconography built into the application submitted to UNESCO in which only one image refers to Pretos Novos Cemetery: a general plan of the area dated 1791. This fact is important since visual resources were key while drafting the dossier, which results in a vast amount of iconographic material including photographs, plans, maps, drawings, and caricatures. The photographs are noteworthy both for the amount (137 photographs) and for the technical and aesthetic care. The absence of images of the cemetery contrasts with the countless photographs of the wharf. Considering the area that makes up the site's buffer zone, there are, for example, two photographs of Pedra do Sal, one of the Hanging Garden of Valongo, and one of D. Pedro II Dock Building.

The emphasis given to the wharf's aesthetics exposes the relationship between the race for World Heritage status and the international tourism industry (Peixoto 2002). The UNESCO advisory agency, by focusing the explanation to register the Wharf (silencing other places of sensitive memories) and its connection with the seafront, demonstrates the strong tourist appeal of heritagization. Setting up a landscape project that recovers this lost relationship with twentieth-century urban reforms, as suggested by ICOMOS (2017), ensures the inclusion of Valongo Wharf in the international tourist itinerary, based on a pacifying aesthetic heritage. Such an aestheticized image stands in opposition to the discomfort caused by the archaeological remains of Pretos Novos Cemetery, which reveals the mortal remains of enslaved Africans and the still-open wounds of colonialism in the city of Rio de Janeiro.

\section{Pretos Novos Cemetery: between silencing and resistance}

The presence of slavery and African heritage have been systematically erased in Rio de Janeiro. Although throughout the nineteenth century, the city was home to the main landing port for enslaved people in the world, there are few references to Africans and African descendants in the territory. Policies for preservation of cultural heritage in this city are still geared towards references to a European heritage, such as properties linked to public management, Catholic religion, and military defence. Thus, the treatment given to Pretos 
Novos Cemetery, where those who died upon arrival at Valongo Wharf or who died in the required quarantine were eventually buried, is an example of silencing material references in history. The cemetery was part of a complex that included the wharf and warehouses where enslaved people were traded. Estimates suggest that during the last six years of operation, more than a thousand people had been buried each year (Pereira 2007). After the ban on the trade of enslaved Africans, ${ }^{14}$ the cemetery became a place for disposal and accumulation of garbage. In the late nineteenth century, the area was taken over by buildings due to urban expansion (Tavares 2012) (Figures 9.2 and 9.3).

In the interviews, the impact of finding the cemetery is profound. To the point of changing career paths of some interviewees and engaging them, at different levels of commitment, to actions geared towards building memories about the diaspora and their ancestors. Actor and cultural producer Hilton Cobra served as director of Cultural Center José Bonifácio (CCJB) in the port area from 1993 to $2000 .{ }^{15} \mathrm{He}$ is the founder of Cia. dos Comuns (theatre group), coordinator of the National Forum of Black Performance and former president of the Palmares Foundation (2013-2014). He refers to the region of Pretos Novos Cemetery as 'the heart of the birthplace of Rio de Janeiro, there in the heart of Black deaths, Black burials when enslaved people would arrive; they were enslaved, never slaves'. He is proud of having worked towards transforming the house where the first remains were found.

Merced's family, the whole family, the girls, her husband and Merced herself, said: 'I'm here digging a treasure. It has to be made available.' ... And it was remarkably interesting. Down here, there was earth. Here,

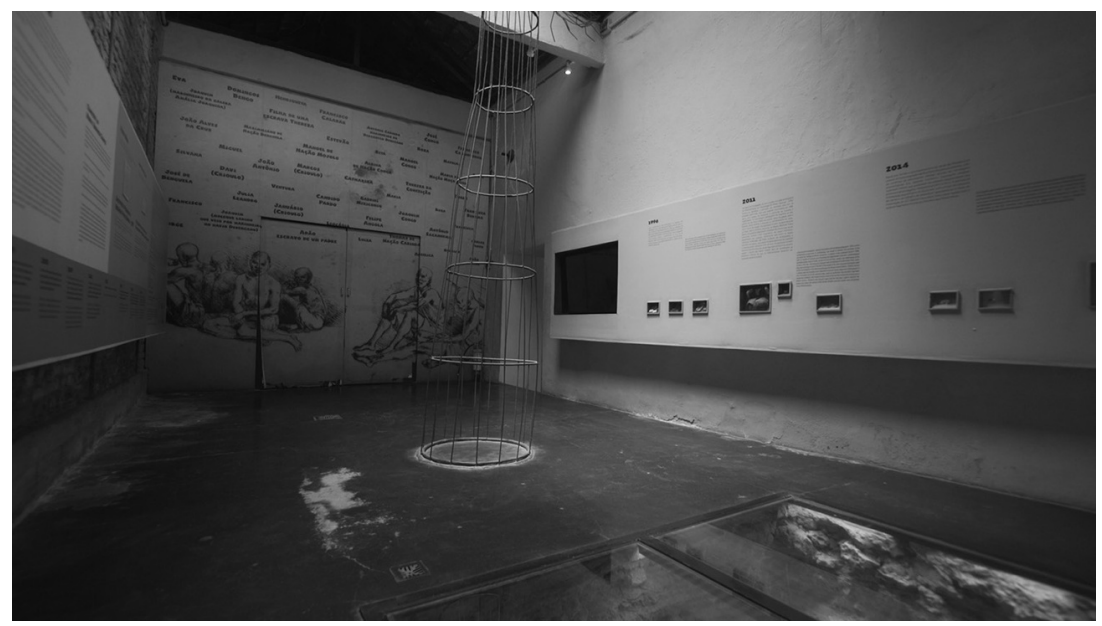

Figure 9.2 Pretos Novos Cemetery on 10 January 2021. Photo courtesy Isabel Palmeira. 


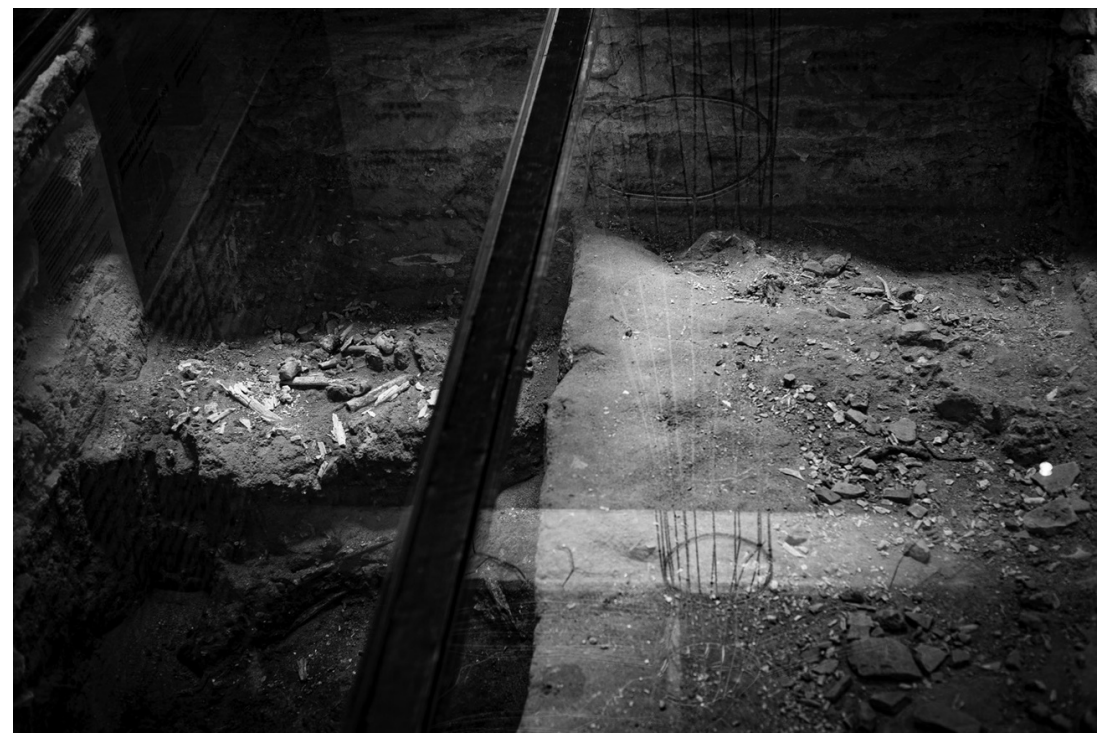

Figure 9.3 Pretos Novos Cemetery on 10 January 2021. Detail of the archaeological showcase displaying buried bodies.

Photo courtesy Isabel Palmeira.

there were mortal remains. Here, there were ornaments. Here, there was earth. Here, there were bones. Here, there were ornaments. It was like that. It was like that. I mean, it is still like that! ... I do not remember exactly what I did, I know I did a lot of work with Merced, so that she could turn that project into what it is today, even though what it is today gets no recognition.

Participating in this project and working as director of a cultural centre in the port region were remarkable experiences in his career: 'It was really more than a job, it was an extraordinary learning experience, I have learned you have to be generous, offering your work to something deeply significant'. During the interview, he emphasized that the traces of colonial slavocrat past and the experiences of people of African descent in the area surrounding the Wharf are important references for residents. Also, he discusses the lack of actions targeted at building and sharing silenced memories:

People who live there, those people look up to this history of the Black world as a reference for their lives.... I would say that the day we make it, I keep saying we, Black people, must create this circuit and revitalize the area to our own benefit - which has been renovated just for them-we will have a Rio de Janeiro, which is 'more better', let's just say it is going to be 'more better', more beautiful, more delicious, more enjoyable with that evident culture, fully exposed. 
Cláudio Honorato is a historian and research coordinator at IPN. ${ }^{16} \mathrm{He}$ first visited the port area as an undergraduate student for a pedagogical research project on enslaved people in the region in the nineteenth century. He comments there was little interaction with the area: 'And, as an undergraduate student, I continued to do research on the port area with no interaction here in the port area. As most researchers do, right?' However, his visit to the cemetery to record an interview in 2007 would develop into an invitation to work as a researcher at the institute, where he still holds a position to this day.

Then, my relationship with the port area grew ever more engaging. I started working here at IPN. Then, we set up Caminhos da Escravidão (Paths of slavery). As universities wished to learn more about the area, they have asked us to make a route. Then, I have made a huge route starting at Praça XV and ending here.

Cláudio Honorato refers to Paths of Slavery, a project he calls pedagogical tourism, which he created in partnership with other IPN researchers. The route's itinerary runs through streets in the port region and includes places, such as Santa Rita Church, Prainha Square, São Francisco da Prainha Church, João da Baiana Square, the Hanging Garden of Valongo, Pedra do Sal, Depósito Square, Harmonia Square, Nossa Senhora da Saúde Church, Cultural Center José Bonifácio, Valongo Wharf, the market where humans were bought and sold, and IPN_-Pretos Novos archaeological site. IPN's central role in building traumatic memories on the diaspora is voiced in accounts by our interviewees in stark contrast to the little attention governmental officials pay to this archaeological site. As a professor and historian who changed the course of his professional life after visiting the cemetery, Cláudio Honorato states: 'Within this process, I identify IPN as one of the greatest guardians of memory, of history in the port area, because it all started there.' Everyone believes there is a need to expand the impact of this finding since thousands of bodies and artefacts have been found here, they embody, in a unique way, the violence of diaspora and show the fate of many enslaved Africans. According to Hilton Cobra:

When you discover an archaeological site that big and in a place like that, governments should protect it, actually enclose it. The place is more than vital to our Black lives. Extraordinary archaeological studies would have to be made available. And those officials, all of them, secretaries, mayors, do not fully understand what that means. And they do not understand the damage resulting from the fact that Merced's project is not fully successful nowadays. If we consider that samba schools have been born there, in that place, that the first enslaved people arrived right there at that wharf, the first enslaved people were buried there, on Pedro Ernesto Street, all that area. 
Although remembrance is very painful, it can be built up through studies of the burials. It can become a source for raising awareness on racial issues in modern day Brazil and an inspiration for resistance. Born in the port area where she still lives to this day, private teacher, and school inspector at a municipal school in the region, Ana Aparecida Guimarães da Silva has extensive experience as a resident and worker in the area. ${ }^{17}$ She is quite proud of the growing appreciation of the 'history of her ancestors':

With Pretos Novos, you know, many children's corpses, corpses of sick people, you know, were thrown and buried that way. So, it was akin to a second Holocaust.... Both those holocausts represent an incredibly sad part of history: slavery and the slave trade, but I feel proud. I like being Black, I want to be Black.

It is important to note that even when referring to events prior to the Second World War, Ana has used the term 'second Holocaust' to demonstrate all the horror involved in slavocrat practices, especially embodied in Pretos Novos Cemetery where many of the bodies of victims of the African diaspora have been found. According to her, the fact that thousands of enslaved people who did not survive mistreatment and the unhealthy environment in the crossing from the African Coast to the city of Rio de Janeiro and were not granted a decent burial is akin to a 'second Holocaust'. She is trying to emphasize the genocide and trauma linked to a historic event that is still silenced.

Our interviewees were acutely aware of the role finding the cemetery has played and the actions to promote IPN in building narratives on the diaspora and processes of redefining blackness towards racial ethnic empowerment. Such awareness contrasts with the limited actions taken by the authorities to preserve it and include it as a part of the history of the area, either by promotion of the site or by funding research. Among the many causes for silencing and neglect towards places of traumatic memories, such as the old cemetery, the continuities between a past and a present of exclusion and violence, the actions of racialization stand out and run deep in the structure of Brazilian society. Similarly, the intrinsic genetic memory in the buried bodies of diaspora victims and its long-term traumatic effects have remained concealed. For a better understanding of this phenomenon, we turn to Valongo Wharf's process of heritagization and the forms of appropriation and resignification of the place when it was turned into a material and symbolic representation of such sensitive memory.

\section{Valongo Wharf: blackness, identities, belonging}

The finding of Valongo Wharf and its later heritagization by UNESCO, associated with major renovation work carried out in the port area aimed at having the government create new leisure and tourist places, has caused 
different impacts on our interviewees. Mônica Lima e Souza has academic standing as a professor at UFRJ. ${ }^{18}$ She holds a PhD in History and is specialized in African History and was very involved in drafting Valongo Wharf's World Heritage dossier as one of the research team members. Along with her as the historian, anthropologist Milton Guran and architect José Pessoa were part of the group. She has taken on a mediating role between the academic world, the institutional world (IPHAN-UNESCO), and social movements utilizing her ability to listen and her good relationship with representatives of Black movements, especially members of Quilombo Pedra do Sal who attended public meetings and negotiations. ${ }^{19}$ Mônica Lima found as she contacted sources during the research process that the 'dimension of pain was fundamental to conceptualizing Valongo Wharf as a historic site of sensitive memory'. According to her, 'nothing in that history was something easy or simple to tell'. She believes that the experience changed her and helped her confront her own story:

Valongo has also meant an encounter, it meant facing myself, my roots, my stories.... So, today, I just think that area is my area, it is my constituency, I have taken that history as part of my own story.

Another interviewee is Celina Maria Rodrigues de Almeida, Yalorixá Mãe Celina de Xangô, priestess of Candomblé. ${ }^{20}$ Since 2007, she has been a coordinator at the Cultural Centre Pequena África located in the Rio de Janeiro port region where she has lived for a few years now after having come from São Gonçalo, a metropolitan region of Rio de Janeiro. Since the 1980s, she often came to the port region to work as a radio broadcaster for Rádio Nacional, located in Mauá Square. She has a personal, religious, and professional relationship with the region. She was directly involved with the research work carried out on Valongo Wharf as a religious consultant providing ancestral knowledge to help identify objects found in the area. Her work on the site came as an invitation by head archaeologist, Tania Andrade Lima, who recognizes her religious knowledge as a path to horizontal dialogue between knowledges (Lima 2013). Celina Maria's first words at the site were 'My God, what am I doing here in this place!' She adds:

It was my great challenge as a mãe de santo [priestess of Candomblé], to set foot in that place, at Valongo Wharf. That was the place where I started over. That was when I truly felt it was my mission. First, to know where I came from, who I am, and where I am going.

Mãe Celina regrets the neglect by public authorities towards the pieces collected on the site: 'I am very sad because two hundred years of our history has been buried, has emerged, and, unfortunately, there is no place to tell the history of slavery'. And she takes ownership of that silenced history: 
If I do not believe that there, that area, that place, even as a mãe de santo, as a Black woman, from a Black family, what am I going to believe in? When I first set foot there, I heard Xango's [Orisha in Yoruba culture known for his powerful axe] voice in my ear going like this: 'your answer is right here'. And so, I have found the answer. So, it meant a grand fresh start, a fresh start on history, a fresh start.

Ana Aparecida Guimarães da Silva speaks with intimacy about the territory. This was her childhood playground with no reference to Valongo Wharf, which does not appear in her memories. However, the theme of African heritage has grown more important in the context of revealing the Wharf remains and undertaking major reforms in the port area in 2011. Ana's narrative underpins the dimension of pain revealed when she says that it touches the human heart, one of your ancestors right there [at the cemetery]. Who knows if one of them is family? Certainly, we are the result of miscegenation'.

Her narrative shows evidence of a self-transforming attitude, building a sense of belonging within history related to the arrival of Black people at the Wharf. She says:

I am still part of history, I feel that it cannot come to an end, Black people's history cannot come to an end. They are the ones who have come, built, and been prevented from entering the places they built, right?

Brazil built its wealth on the backs of enslaved people with a complete disregard to their humanity, and the enslaved have been expropriated and excluded from history. Transforming the Wharf into a piece of merchandise in which the enslaved have been placed as subjects of history does not comply with the end of the process of enslavement. However, resistance against silencing memories of struggle and gradually implementing reparation measures is a daily exercise performed by African descendants in Brazil over the long post-abolition period. Ana Aparecida Guimarães da Silva has also spoken of the positivity of Black bodies because she is gaining appreciation of the physical traits of her blackness: 'Oh, each passing day, we have been showing ourselves more appreciation, we have been letting our hair grow naturally, [it's] so good growing our hair the way it is'. According to Nilma Lino Gomes (2002), curly hair shows blackness on bodies, as Black identity is materialized and embodied. Hair and body affirmation for Black people is also a strategy of resistance.

The three women interviewed, Mônica Lima e Souza, Celina Maria Rodrigues de Almeida, and Ana Aparecida Guimarães da Silva, reveal a process of identity building as it relates to their blackness when talking about themselves by following a common path: direct contact with the dimension of suffering caused by slavery is felt as their own pain. And, in light of this, 
they see themselves as part of history, taking on a decolonial attitude that breaks away from mainstream silencing.

Becoming part of Brazilian history, these women seeing themselves as subjects of history, means building a broader belonging to the nation 'they have built and have been prevented from entering', as Ana Aparecida said. Similarly, Mônica Lima, upon acknowledging that this history is also her own, claims 'I have embraced this history as part of my own story'. And Mãe Celina said that it has drastically changed her life and given her 'a grand fresh start, a fresh start on history'. Overall, being included in history comes as a finding, a rite of recognition to the pain experienced by their ancestors, which mirrors their own stories. Such finding shows the structural absence of Black people in narratives about the Brazilian past.

\section{Heritage and memories on the move}

The historic singularity in the process of shaping structural racism in Brazil manifests itself in racial democracy ideology. With his work The Masters and the Slaves, published in 1933, Gilberto Freyre ([1933] 1995) systematized theories on racial democracy that had been discussed since the late nineteenth century and gained great effect and longevity in Brazilian social thought. Freyre described violence and inequality as circumstantial and not structural in colonial society, when referring to miscegenation processes between white, Black, and Indigenous people, which resulted in a mixed-race population and harmonious social relations (Castelo 1998). Kabengele Munanga, questioning Freyre's theses, states that 'miscegenation underpins discriminatory expectations because Black people are supposed to become light-skinned, instead of being accepted as they are' $(2010,450)$. According to Silvio Luiz de Almeida (2018), racial democracy ideology has rendered bodies domesticated and made commonplace unequal ways of living.

Humanization processes, which were unthinkable when slavery was legal, Michel-Rolph Trouillot (1995) suggests that to this day they carry ambiguities related to possible reality as seen in our interviewees' narratives. What is deemed unthinkable in the mainstream worldview prevails to the detriment of facts. In other words, although racial discrimination is a non-bailable offence in Brazil, in real terms it has been incorporated, recognized, naturalized and, therefore, in most cases, it has become invisible, unprecedented, silenced. Despite referring to another temporality and context, Trouillot's statement seems to refer to present-day Brazil: 'Worldview wins over the facts: white hegemony is natural and taken for granted; any alternative is still in the domain of the unthinkable' $(1995,93)$. Racial ethnic empowerment, which may occur because of racialization contexts, is the result of displacements that have taken place within the scope of subjectivity establishing a connection to an envisioned collective be it Black women, Black movements, the Brazilian nation. Manifested in resistance to discrimination, Black people created a narrative for racial identity in which 
phenotypic traits have been turned into something positive and have become a way of affirmation for people, that is, voices aware of their power.

The Rio de Janeiro port region is also known as Little Africa because of the massive presence of African descendants. The area has been recognized as the birthplace of Rio-native samba because of the samba circles (rodas de samba) held there accompanied by Black musicians, composers of this new rhythm. ${ }^{21}$

Archaeological excavations that resulted in exposing the remains of Pretos Novos Cemetery since the 1990s and the Valongo Wharf since 2011 have caused varied effects. Urban reform planners had not foreseen some of those effects in the region, such as new forms of cultural appropriation increasingly seeking to update the memory of blackness in the territory. Such memory has been progressively silenced throughout the twentieth century by means of deterioration and neglect of the port area as well as marginalization of local population. However, there are countless performances taking place in that area, reinforcing the Black territorialities defined by Little Africa, such as physical, symbolic violence as well as resistance. Among those, we highlight washing the Wharf (lavagem do Cais) held once a year by D. Celina and two other priestesses of Candomblé and the frequent capoeira circles (rodas de capoeira), on the stones around the Wharf. ${ }^{22}$ Carnival parades for blocosorganized, often theme-based, groups that come together to party during Carnival - such as Escravos da Mauá and Prata Preta can also be mentioned as they occupy places of great symbolic value for the memory of Black people's struggle, in the same way CCJB, by Hilton Cobra, and Harmonia Square, by Claudio Honorato, are mentioned. ${ }^{23}$ Frequent guided tours in the African Heritage Circuit of a touristic or pedagogical nature are still some of the performances that keep the streets in the region bustling. ${ }^{24}$ Resistance is also expressed in the struggle of Quilombo da Pedra do Sal whose former residents remained in their homes, even after gentrification because of the major urban reform carried out in the area by the Porto Maravilha project. All those manifestations demonstrate how vibrant African-based cultural expressions are in many symbolic places. The exercise of listening, via oral history, has enabled us to show the presence of plural, contradictory stories, neutralizing the single history stemming from silencing actions. Therefore, it has also offered new meanings to vestiges recognized as colonial heritage, favouring decolonization movements, which are multiple and diverse.

Throughout this chapter, the secondary aspect of Pretos Novos Cemetery was analysed despite all the evidence that it was a key part of the complex spearheaded by Valongo Wharf, revealing tensions and disputes in the process of heritagization on local and global scales. This operation, in turn, was opposed to the narratives of the people whose voices highlighted the importance of encountering the discomfort and pain the cemetery evokes. There are multiple pieces of heritage and memories in motion, forging stories of racial ethnic empowerment, inclusion, and belonging while also creating stories of exclusion, whitening, and the strength of economic power. 
Building narratives on ancestry and the African presence in Brazil, as well as the very conditions of existence related to race, belong to processes of empowerment and belonging, as shown by our interviewees' statements. They are expressions of the anti-racist struggle, as a tactic or subversion (Certeau 1984) and to incorporate new practices of resistance based on facing discrimination.

\section{Notes}

1 This work forms part of the ECHOES project which has received funding from the European Union's Horizon 2020 research and innovation programme under grant agreement No. 770248.

2 Porto Maravilha was a great undertaking carried out by the government in the Rio de Janeiro port area. The project aimed at a tourist boom expected for the 2016 Olympics and 2014 World Cup. It caused a brutal transformation in the area. See Maria Lucia Borges de Faria (2016).

3 Pedra do Sal is a large stone with stairs carved by enslaved people in the nineteenth century. In 1986, Pedra do Sal was hailed as a monument for Black culture by the Rio de Janeiro's Institute of Cultural Heritage (INEPAC, acronym in Brazilian Portuguese). That was the first and only act of recognition of the presence of Black culture in the port area.

4 All translations are our own unless otherwise noted.

5 The interviews were conducted by Brenda Coelho, Keila Grinberg, Isabel Palmeira, Leila Aguiar, Márcia Chuva, and Tâmisa Caduda. Interviewees chose the location of the interviews, which was meant to make them feel more comfortable. Interviews lasted from 50 to 120 minutes. Edited versions of the interviews are available on the website for University of Coimbra's Centre for Social Studies (CES): https://www.ces.uc.pt/echoes-wp4/lifestories

6 An interview with Merced Guimarães was conducted by researchers from Fluminense Federal University's Oral History and Historiography Laboratory (LABHOI). Another interview is available: "Merced Guimarães relata a crueldade da história do maior cemitério de escravos das Américas," Youtube, 8 March 2021. https://www.youtube.com/watch?v=bo1rQJAs5xs\&t=114s

7 Brazil's SEPPIR was founded in 2003 under President Lula da Silva's administration. In 2015, it was incorporated into the Ministry of Women, Racial Equality and Human Rights. During President Bolsonaro's administration, Sérgio Camargo, President of the Palmares Cultural Foundation, has been working actively against Black movements. Therefore, by Presidential design, the Palmares Foundation no longer serves its founding purposes.

8 Milton Guran served on the Slave Route Project's Scientific Committee while drafting of the inventory was under way. In 2015, he took office as Coordinator for the Working Group on Valongo Wharf's candidacy.

9 Amongst the fifteen Brazilian inscriptions on the World Heritage List, other than the Valongo Wharf, there are ten colonial cities and colonial Catholic buildings, two sites of modern architecture, one archaeological park with millennia-old cave paintings, and Rio de Janeiro as cultural landscape. For further information, please refer to "Patrimônio Mundial," IPHAN. Accessed 4 March 2021. http://portal.iphan.gov.br/pagina/detalhes/24.

10 Survey carried out by the authors on UNESCO's website in July 2020. "World Heritage List," UNESCO. Accessed 4 March 2021. https://whc.unesco.org/en/list/.

11 Registering the Angolan site Mbanza Kongo in the same year as the Wharf is a good example of keeping mainstream narratives. The former Kongo kingdom, 
which played a crucial role in the trade of enslaved Africans, was recognized as a World Heritage Site due to the emphasis on Portuguese presence and as a gateway to Christianity on the African continent (République d'Angola 2016).

12 A 'buffer zone' is 'an area surrounding the nominated property that has complementary legal and/or customary restrictions placed on its use and development to give an added layer of protection to the property. This should include the immediate setting of the nominated property, important views and other areas or attributes that are functionally important as a support to the property and its protection' (UNESCO 2017b, 30).

13 In 2011, the central role played by the Wharf in the Historic and Archaeological Circuit to Celebrate African Heritage, created by a decree enacted by the City of Rio de Janeiro, was subjected to criticism by Black movements, especially because the cemetery was once again overlooked (Vassallo and Cicalo 2015, 258).

14 In 1831, the Brazilian Congress enacted the Feijó Law, which set forth that all enslaved people who entered Brazilian territory by land or through ports, coming from abroad, would be free. This law, however, was not properly followed. Therefore, the international trade of enslaved Africans in Brazil was only brought to an end in 1850 upon passing of the Eusébio de Queiroz Law.

15. Interview conducted with Hilton Cobra in December 2019 in the gardens of Chácara do Céu Museum. CCJB was set up in 1986. During the 1990s, under the management of Hilton Cobra, it became a reference centre for Afro-Brazilian culture. Over that period, Cobra was responsible for setting up a series of shows and exhibitions with Black artists and issues related to blackness as well as organizing a bibliographic collection related to Afro-Brazilian culture.

16 Interview conducted in August 2019 at IPN.

17 Interview conducted in December 2019 at her home.

18 Interview conducted in December 2019 at UFRJ History Institute.

19 Quilombo Pedra do Sal, located in the Rio de Janeiro port region, is an area listed by Palmares Foundation as a remaining quilombo community. Located on the large stone with stairs carved in the nineteenth century by enslaved people, it was granted protection as a Black culture monument in 1986.

20 Interview conducted in June 2019 at her home.

21 Among them Donga, Pixinguinha, João da Bahiana. For further information on the history of samba in Rio de Janeiro, refer to Martha Abreu (2017).

22 Priestesses of Candomblé who joined are Mãe Edelzuita de Oxaguian, Mãe Beata de Iemanjá, as well as Mãe Celina de Xangô.

23 In his interview, Claudio Honorato has referred to Harmonia Square as a place of historic urban uprisings, such as the 1904 Revolta da Vacina (Vaccine revolt), when the population refused to be vaccinated against smallpox. People have set up barricades in that square and several other areas in the city. For further information on the subject, refer to Nicolau Sevcenko (1983).

24 For some of those circuits and highlights, see "Passados Presentes: Memories of Slavery in Brazil," Pasts Presents - Memories of Slavery in Brazil. Accessed 4 March 2021. http://passadospresentes.com.br/site/Site/index.php

\section{References}

Abreu, Martha. 2017. Da senzala ao palco: canção escrava e racismo nas América, 1870-1930. Campinas: Editora da Unicamp. Kindle.

Araújo, Ana Lucia, ed. 2015. African Heritage and Memories of Slavery in Brazil and South Atlantic World. Amherst: Cambria Press.

Castelo, Cláudia. 1998. O modo português de estar no mundo: O luso-tropicalismo e a ideologia colonial portuguesa (1933-1961). Porto: Afrontamento. 
de Certeau, Michel. 1984. The Practice of Everyday Life. Berkeley: University of California Press.

République d'Angola. 2016. "Proposition d'inscription sur la liste du patrimoine mondial - Mbanza Kongo, Vestiges de la Capitale de L'ancien Royaume du Kongo." Luanda: INPC.

de Almeida, Silvio Luiz. 2018. O que é racismo estrutural? Belo Horizonte: Letramento. de Faria, Maria Lucia Borges. 2016. Preservação do Patrimônio Cultural Urbano no Porto Maravilha, Rio De Janeiro: Disputas e deslocamentos de sentido nas políticas, práticas e instrumentos. Niterói: Tese de Doutorado Arquitetura e Urbanismo. UFF. Freyre, Gilberto. 1995 [1933]. Casa Grande \& Senzala. Rio de Janeiro: Record.

Gomes, Nilma Lino. 2002. Sem perder a raiz: Corpo e cabelo como símbolos da identidade negra. Belo Horizonte: Autêntica.

ICOMOS (International Council of Monuments and Sites). 2016. "Valongo Wharf Archaeological Site: Interim Report." World Heritage List 2017. Charenton-lePont: ICOMOS.

ICOMOS (International Council of Monuments and Sites). 2017. "Evaluations of Nominations of Cultural and Mixed Properties: ICOMOS Report for the World Heritage Committee 41st Ordinary Session.” Accessed 8 March 2021. http://whc. unesco.org/archive/2017/whc17-41 com-inf8B1-en.pdf.

IPHAN (Instituto do Patrimônio Histórico e Artístico Nacional). 2017. "Proposal for Inscription on the World Heritage List: Valongo Wharf Archaeological Site." Brasília: IPHAN.

Lima, Tania Andrade. 2013. "Arqueologia como ação sociopolítica: o Cais do Valongo, Rio de Janeiro, séc. XIX." Vestígios: Revista Latino-Americana de Arqueologia Histórica 7 (1): 177-207.

Mattos, Hebe, Martha Abreu, and Milton Guran. 2013. "Inventário dos Lugares de Memória do Tráfico Atlântico de Escravos e da História dos Africanos Escravizados no Brasil." LABHOI. Accessed 08 March 2021. http://www.labhoi.uff.br/sites/ default/files/inventario_julho_2013.pdf

Mattos, Hebe, Martha Abreu, and Milton Guran. 2014. "Por uma história pública dos africanos escravizados no Brasil." Estudos Históricos 27 (54): 255-73.

Mignolo, Walter. 2011. The Darker Side of Western Modernity. Durham: Duke University Press.

Munanga, Kabengele. 2010. "Mestiçagem como símbolo da identidade brasileira.” In Epistemologias do Sul, edited by Boaventura de Souza Santos and Maria Paula Meneses, 444-54. São Paulo: Cortez.

OAU (Organization of African Unity). 1992. "Resolutions Adopted by the Fiftysixth Ordinary Session of the OAU Council of Ministers," OAU. Accessed 6 March 2021.https://au.int/sites/default/files/decisions/9616-council_en_22_28_june_1992_ council_ministers_fifty_sixth_ordinary_session.pdf.

Peixoto, Paulo. 2002. "A Corrida ao Status de Patrimônio Mundial e o Mercado Urbano de Lazer e Turismo." Veredas - Revista Científica de Turismo 1 (1): 23-45.

Pereira, Júlio César Medeiros da Silva. 2007. À flor da terra: o cemitério dos pretos novos no Rio de Janeiro. Rio de Janeiro, Garamond: IPHAN.

Santos, Boaventura de Souza. 2014. "Beyond the Abyssal Thinking: From Global Lines to Ecologies of Knowledges." In Epistemologies of the South: Justice against Epistemicide, edited by Boaventura de Souza Santos and Maria Paula Meneses, 118-35. London New York: Routledge.

Sevcenko, Nicolau. 1983. A Revolta da Vacina, mentes insanas em corpos rebeldes. São Paulo: Brasiliense. 
Smith, Laurajane. 2006. The Uses of Heritage. New York: Routledge.

Tavares, Reinaldo Bernardes. 2012. "Cemitério dos pretos novos, Rio de Janeiro, século XIX: uma tentativa de delimitação espacial.” PhD diss., Arqueologia do Museu Nacional, UFRJ, Rio de Janeiro.

Thompson, Paul. 1990. I Don't Feel Old: The Experience of Later Life. Oxford: Oxford University Press.

Thompson, Paul. 2006. "Histórias de vida como patrimônio da humanidade." In História falada: memória, rede e mudança social., edited by Karen Worcman and Jesus Vásquez Pereira. São Paulo: Sesc-Museu da Pessoa.

Trouillot, Michel-Rolph. 1995. Silencing the Past: Power and the Production of History. Boston: Beacon Press.

UN. 2001. "Declaration of the World Conference against Racism, Racial Discrimination, Xenophobia and Related Intolerance," UN. Accessed 8 March 2021. https://www.un.org/en/ga/durbanmeeting2011/pdf/DDPA_full_text.pdf.

UNESCO. 1993. "Records of the General Conference - Twenty-seventh Session." UNESCO. Accessed 8 March 2021. https://unesdoc.unesco.org/ark:/48223/ pf0000095621/PDF/095621eng.pdf.multi.nameddest $=5 \% 3 \mathrm{E}$

UNESCO. 2002. "Decisions Adopted during the 26th Session of the World Heritage Committee," UNESCO. Accessed 7 March 2021. https://whc.unesco.org/ archive/2002/whc-02-conf202-25e.pdf

UNESCO. 2017a. "Decisions Adopted during the 41st Session of the World Heritage Committee," UNESCO. Accessed 7 March 2021. https://whc.unesco.org/ archive/2017/whc17-41com-18-en.pdf

UNESCO. 2017b. "Operational Guidelines for the Implementation of the World Heritage Convention." Paris: Intergovernmental Committee for the Protection of the World Cultural and Natural Heritage (World Heritage Committee).

Vassallo, Simone, and André Cicalo. 2015. "Por onde os africanos chegaram: o Cais do Valongo e a institucionalização da memória do tráfico negreiro na região portuária do Rio de Janeiro.” Horizontes Antropológicos 21 (43): 239-71

Vergès, Françoise. 2020. Um feminismo decolonial. São Paulo: Ubu. 